\title{
Growth and metal uptake of energy sugarcane (Saccharum spp.) in different metal mine tailings with soil amendments
}

\author{
Xin Zhang ${ }^{1}$, Yongguan Zhu ${ }^{1,2}$, Yuebin Zhang ${ }^{3}$, Yunxia Liu ${ }^{1}$, Shaochun Liu $^{3}$, Jiawen Guo ${ }^{3}$, \\ Rudan $\mathrm{Li}^{3}$, Songlin $\mathrm{Wu}^{1}$, Baodong $\mathrm{Chen}^{1, *}$ \\ 1. State key Laboratory of Urban and Regional Ecology, Research Center for Eco-Environmental Sciences, Chinese Academy of Sciences, Beijing \\ 100085, China. E-mail: xinzhang@rcees.ac.cn \\ 2. Key Lab of Urban Environment and Health, Institute of Urban Environment, Chinese Academy of Sciences, Xiamen 361003, China \\ 3. Sugarcane Research Institute, Yunnan Academy of Agricultural Sciences, Yunnan 661600, China
}

A R T I C L E IN F O

\section{Article history:}

Received 22 September 2013

revised 30 October 2013

accepted 07 November 2013

\section{Keywords:}

bioenergy crop

sugarcane

metal mine tailings

phytoremediation

DOI: 10.1016/S1001-0742(13)60543-4

\begin{abstract}
A B S T R A C T
A pot experiment was conducted to investigate the feasibility of growing energy sugarcane (Saccharum spp.) in three different metal mine tailings ( $\mathrm{Cu}, \mathrm{Sn}$ and $\mathrm{Pb} / \mathrm{Zn}$ tailings) amended with uncontaminated soil at different mixing ratios. The results indicated that sugarcane was highly tolerant to tailing environments. Amendments of $20 \%$ soil to $\mathrm{Sn}$ tailings and $30 \%$ soil to $\mathrm{Cu}$ tailings could increase the biomass of cane-stem for use as the raw material for bioethanol production. Heavy metals were mostly retained in roots, which indicated that sugarcane was useful for the stabilization of the tailings. Bagasse and juice, as the most valuable parts to produce bioethanol, only accounted for $0.6 \%$ $3 \%$ and $0.6 \%-7 \%$ of the total metal content. Our study supported the potential use of sugarcane for tailing phytostabilization and bioenergy production.
\end{abstract}

\section{Introduction}

Mining activities can produce huge amounts of mine tailings. Without proper storage and rehabilitation, the tailings may leach into soil and water bodies (Kien et al., 2010), resulting in environmental contamination and then human health concerns. Furthermore, mine tailings threaten natural vegetation owing to their lower $\mathrm{pH}$ and a composition consisting of mostly silt or sand-sized particles, lacking water retention capacity and fertility (Mendez et al., 2007; Rosario et al., 2007; Ye et al., 2002). In China, mining activities have generated about 3.2 Mha wasteland, and the area impacted is still increasing at a rate of 46,700 ha per year (Li et al., 2007). Gejiu City of Yunnan Province in south-west China is rich in tin

\footnotetext{
*Corresponding author. E-mail: bdchen@ $@$ rcees.ac.cn
}

and other mineral deposits, including lead/zinc and copper mines. It produced $223 \mathrm{Mt}$ mining waste and destroyed a total of about 1671 ha land area as of 2002 (Li, 2006), which seriously affected the sustainable socio-economic development of the region. Obviously, there is an urgent demand for proper management of mine tailings.

Conventional technologies for the remediation of mine tailings such as soil excavation, landfilling or soil washing mainly involve physical and chemical methods. However, owing to the large quantity of mine tailings, decontamination by such conventional methods appears to be unfeasible due to the high cost and secondary pollution involved. In the long run, the establishment of vegetation cover is recognized as a sustainable approach that can fulfill the objectives of stabilization, pollution control and visual improvement (Wong, 2003). However, usually the ecological restoration of mining-impacted land is a big challenge. 
Suitable substrate amendment and selection of suitable plant species for planting on mine wastes are critical steps for revegetation practice. Covering the mine tailings with topsoil from an un-mined site is a commonly accepted strategy for the successful establishment of vegetation cover. Plants selected should be tolerant to specific metals, drought or infertile conditions (Wong, 2003), and growth of edible crops on mine tailings should be avoided owing to health risks to humans. Alternatively, planting energy crops which can adapt to adverse conditions is considered to be a good choice, as it could potentially mitigate the soil contamination and the gradual reduction of fossil fuels at the same time (Olivares et al., 2013). As seen in reports, several researchers have postulated this new strategy of cultivating energy plants, including rapeseed, wheat, corn, castor bean, vetiver grass and willow in metalcontaminated soils for bioenergy production (Hargreaves et al., 2012; Liu et al., 2012; Luu Thai et al., 2011; Van Danh et al., 2007; Witters et al., 2012).

As an important crop in the tropics and subtropics, sugarcane (Saccharum spp.) belongs to the Hatch-Slack crop type and fixes solar energy efficiently. It is regarded as one of the three largest biomass energy crops worldwide. Its annual output amounts to 40-120 tons/ha and the dry shoot weight can reach 12.8 tons/ha, with superior growth compared to most other crop species (Alexander, 1973). The Brazilian National Company of Food Supply estimated that 432 Brazilian mills and distilleries crushed a total of 625 million tons of sugarcane and produced 27 billion liters of bioethanol in 2010 (Amorim et al., 2011). Such productivity led Brazil to become the second largest ethanol producer in the world, responsible for $37 \%$ $\left(2.4 \times 10^{7} \mathrm{~m}^{3}\right)$ of the global annual production $(6.56 \times$ $10^{7} \mathrm{~m}^{3}$ ) (Souza et al., 2012). Moreover, sugarcane has a vigorous root system with the maximum root depth exceeding $6 \mathrm{~m}$, which can extract water and nutrients from considerable depths and make use of water up-flow from water tables (Smith et al., 2005). As a result, it can combat adverse conditions and tolerate dry, salty, or contaminated environments (Wahid, 2004; Wahid et al., 1997). Sugarcane plantlets were able to tolerate up to 100 $\mathrm{mmol} / \mathrm{L}$ of copper in nutrient solution for 33 days, with no significant reduction in fresh weight and accumulating 45 $\mathrm{mg} / \mathrm{kg} \mathrm{Cu}$ on a shoot dry weight basis (Sereno et al., 2007). Xia et al. (2009) also investigated the growth and heavy metal accumulation of sugarcane that grew on artificially contaminated soil with different concentration of $\mathrm{Cd}$, and found sugarcane had a high ability to tolerate and accumulate $\mathrm{Cd}$ with its large biomass. The feasibility of adopting edible sugarcane for restoration of manganese mining sites has been investigated, and it was found that $\mathrm{Cd}$ and $\mathrm{Pb}$ concentrations were higher than the safety limits in the edible parts of sugarcane. Researchers mentioned that such a product was unacceptable as food and this agricultural restoration pattern should be carefully reconsidered $(\mathrm{Li}$ et al., 2007). Alternatively, sugarcane could potentially serve as reclamation species for mine tailings owing to its outstanding biomass production, robust root system and strong adaptability to the adverse environment.

Despite the fact that energy sugarcane could adapt to certain adverse conditions and be efficient in bioethanol production, its heavy metal tolerance and potential for phytoremediation when growing in mine tailings have not been examined. Here we carried out a pot experiment to test the feasibility of growing energy sugarcane on three different metal mine tailings ( $\mathrm{Cu}, \mathrm{Sn}$ and $\mathrm{Pb} / \mathrm{Zn}$ tailings). To assist successful planting, soil amendment was also considered. The objectives of the study were therefore to (1) investigate the metal accumulation and tolerance of sugarcane in different mine tailings; (2) examine the need for soil amendments to support plant growth; (3) evaluate whether sugarcane could serve as an energy crop in mining areas.

\section{Material and methods}

\subsection{Experimental material}

$\mathrm{Cu}, \mathrm{Sn}$ and $\mathrm{Pb} / \mathrm{Zn}$ mine tailings were collected from an ore-dressing plant of Gejiu City, Yunnan Province. Uncontaminated soil for amendment was collected from a paddy field in the Sugarcane Research Institute of Yunnan Agricultural Academy of Sciences. The total heavy metal concentrations in different tailings and soil (digested by a mixture of concentrated $\mathrm{HNO}_{3}, \mathrm{HCl}$ and $\mathrm{HClO}_{4}$ ) and DTPA-metal available concentrations (Lindsay and Norvell, 1978) are listed in Table 1. The physico-chemical properties of uncontaminated soil and the three mine tailings are shown in Table 2. Soil chemical properties were determined by procedures recommended by Richards (1954). The $\mathrm{pH}$ value (1: 2.5 soil to water) of the mixture of different metal mine tailings with soil are listed in Table 3. The sugarcane cultivar selected was Funong 94-0403.

\subsection{Experimental conditions}

Mine tailings and soils were air dried and passed through a $2 \mathrm{~mm}$ sieve. Different mine tailings $(\mathrm{Cu}, \mathrm{Pb} / \mathrm{Zn}, \mathrm{Sn})$ were thoroughly mixed with soils at a mixing ratio of 7:3, 8:2 and 9:1 $(\mathrm{m} / \mathrm{m})$ respectively. Together with a control treatment with soil alone, there were a total of 10 treatments. Each treatment had four replicates. Black plastic pots having $30 \mathrm{~cm}$ in height, $38 \mathrm{~cm}$ in top and $28 \mathrm{~cm}$ in bottom diameter, were used as growth containers. Each container accommodated $20 \mathrm{~kg}$ of the mixed soil and mine tailings. Three bud sets of sugarcane were planted in each pot. The $10 \mathrm{~g}$ compound fertilizer $\left(\mathrm{N}-\mathrm{P}_{2} \mathrm{O}_{5}-\mathrm{K}_{2} \mathrm{O}\right.$ of 14:15:16 $(\mathrm{m} / \mathrm{m})$ ) was added 42 days after planting, and $5 \mathrm{~g}$ carbamide was added to each pot 92 and 147 days after planting. The pots were kept outdoors with a natural photoperiod of 12-13 
Table 1 Total and DTPA-extractable metal concentration in uncontaminated soil and three mine tailings

\begin{tabular}{|c|c|c|c|c|c|c|c|c|}
\hline \multirow[t]{2}{*}{ Growth medium } & \multicolumn{4}{|c|}{ Total metal concentration $(\mathrm{mg} / \mathrm{kg})$} & \multicolumn{4}{|c|}{ DTPA extractable metal concentation $(\mathrm{mg} / \mathrm{kg})$} \\
\hline & $\mathrm{Cu}$ & $\mathrm{Sn}$ & $\mathrm{Pb}$ & $\mathrm{Zn}$ & $\mathrm{Cu}$ & Sn & $\mathrm{Pb}$ & $\mathrm{Zn}$ \\
\hline Soil & 75.99 & 7.18 & 622.80 & 158.93 & 2.33 & 2.53 & 7.12 & 2.41 \\
\hline $\mathrm{Cu}$ tailings & 6484.33 & 35.65 & 13305.00 & 1921.75 & 553.36 & 7.59 & 250.54 & 159.51 \\
\hline Sn tailings & 962.57 & 62.35 & 13102.50 & 3070.00 & 72.60 & 6.34 & 589.13 & 144.10 \\
\hline $\mathrm{Pb} / \mathrm{Zn}$ tailings & 965.50 & 60.13 & 57930.00 & 10625.00 & 80.53 & 5.42 & 1581.41 & 934.89 \\
\hline
\end{tabular}

DTPA: diethylene triamine pentacetate acid.

Table 2 Physico-chemical properties of uncontaminated soil and three mine tailings

\begin{tabular}{lllllllll}
$\begin{array}{l}\text { Growth } \\
\text { medium }\end{array}$ & $\mathrm{pH}$ & $\begin{array}{c}\text { Organic matter } \\
\text { content }(\mathrm{g} / \mathrm{kg})\end{array}$ & $\begin{array}{l}\text { Total N } \\
(\mathrm{g} / \mathrm{kg})\end{array}$ & $\begin{array}{l}\text { Total P } \\
(\mathrm{mg} / \mathrm{kg})\end{array}$ & $\begin{array}{l}\text { Total K } \\
(\mathrm{mg} / \mathrm{kg})\end{array}$ & $\begin{array}{c}\text { Ammoni-acal } \\
\text { nitrogen }(\mathrm{mg} / \mathrm{kg})\end{array}$ & $\begin{array}{c}\mathrm{NH}_{4} \text { Ac-extractable } \\
\mathrm{K}(\mathrm{mg} / \mathrm{kg})\end{array}$ & $\begin{array}{c}\text { Olsen-P } \\
(\mathrm{mg} / \mathrm{kg})\end{array}$ \\
\hline Soil & 4.71 & 25.46 & 1.84 & 1552.75 & 3067.5 & 58.25 & 204.07 & 18.25 \\
Cu tailings & 8.19 & 3.41 & 0.27 & 859.25 & 2745 & 32.73 & 60.25 & 12.52 \\
Sn tailings & 8.53 & 1.10 & 0.20 & 930.75 & 1188.75 & 33.38 & 19.42 & 7.10 \\
$\mathrm{~Pb} /$ Zn tailings & 8.35 & 10.37 & 0.17 & 980.50 & 999.25 & 35.85 & 26.19 & 4.79 \\
\hline
\end{tabular}

Table 3 pH value of the mixture of different metal mine tailings with soil

Tailing type Mixing ratios of soil with the tailings $(\mathrm{m} / \mathrm{m})$

\begin{tabular}{llll}
\cline { 2 - 4 } & $7: 3$ & $8: 2$ & $9: 1$ \\
\hline Cu tailings & 7.07 & 7.36 & 7.71 \\
Sn tailings & 7.11 & 7.30 & 7.60 \\
$\mathrm{~Pb} /$ Zn tailings & 7.07 & 7.24 & 7.61 \\
\hline
\end{tabular}

$\mathrm{hr}$ and the monthly average temperature was $13.1-24.8^{\circ} \mathrm{C}$. Deionized water was supplied to near field capacity at 72 $\mathrm{hr}$ intervals throughout the growth period.

\subsection{Experimental harvest}

Eleven months after planting, leaf, stem and root were harvested separately. The stem was roughly cut into three parts (bottom, middle and top part), then the juice was pressed out from each part by a sugarcane press and the bagasse was left. The sucrose content, reducing sugar, fiber fraction, juice yield and heavy metal concentration in subsamples of sugarcane juice were determined. Root samples were then carefully washed with tap water followed by deionized water to remove adhering soil particles. Leaf, bagasse and root were oven dried at $80^{\circ} \mathrm{C}$ for $48 \mathrm{hr}$ after the fresh biomass was recorded. Then each part was milled to a fine powder prior to chemical analysis.

\subsection{Chemical analysis}

Approximately $0.2 \mathrm{~g}$ oven-dried plant material was weighed into $50 \mathrm{~mL}$ polypropylene digestion tubes and steeped in $2 \mathrm{~mL}$ of high-purity nitric acid. The $1.5 \mathrm{~mL}$ sugarcane juice were also added into $50 \mathrm{~mL}$ polypropylene digestion tubes and mixed with $2 \mathrm{~mL}$ of high-purity nitric acid. The mixtures were allowed to stand overnight, and then heated in a microwave accelerated reaction system (CEM Microwave Technology Ltd., Matthews, USA). The temperature was first raised to $55^{\circ} \mathrm{C}$ and then to $75^{\circ} \mathrm{C}$, with holding time of $10 \mathrm{~min}$. Finally the digest was heated at $95^{\circ} \mathrm{C}$ for $30 \mathrm{~min}$ before cooling. The digests were made up to a volume of $25 \mathrm{~mL}$ with ultrapure water $(18.2 \mathrm{M})$. The concentrations of $\mathrm{Sn}, \mathrm{Pb}, \mathrm{Cu}$ and $\mathrm{Zn}$ in the digests were determined by inductively coupled plasmamass spectrometry (ICP-MS, 7500a Agilent Technologies, Palo Alto, USA). A reagent blank and a certified reference material (bush twigs and leaves, GBW07603 from the National Research Center for Standard Materials in China) were included for quality assurance. The juice quality indexes including sucrose content, reducing sugar, fiber fraction and juice yield were determined according to Guo et al. (2012).

\subsection{Data analysis}

Data were subjected to two-way or three-way (for sugarcane juice and bagasse) ANOVA to compare mixing ratio, tailings species and sugarcane part using Windows-based SPSS 16.0. The differences between means were determined using Duncan's Multiple Test at 0.05 probability level.

\section{Results}

\subsection{Biomass}

Compared to the control treatment (soil only), the root biomass increased with mine tailings in the growth medium $(p<0.01$, Table 4). Sugarcane grown in $70 \% \mathrm{Sn}$ 
Table 4 Fresh weight $(\mathrm{kg})$ of different parts of sugarcane grown in mine tailings mixed with soil at different mixing ratios

\begin{tabular}{|c|c|c|c|c|c|c|c|c|c|c|c|c|c|}
\hline \multirow{2}{*}{$\begin{array}{l}\text { Part of } \\
\text { sugarcane }\end{array}$} & \multirow[t]{2}{*}{ Control } & \multicolumn{3}{|c|}{$\mathrm{Cu}$ tailings:Soil } & \multicolumn{3}{|c|}{ Sn tailings:Soil } & \multicolumn{3}{|c|}{$\mathrm{Pb} / \mathrm{Zn}$ tailings:Soil } & \multicolumn{3}{|c|}{ Significance } \\
\hline & & $7: 3$ & $8: 2$ & $9: 1$ & $7: 3$ & $8: 2$ & $9: 1$ & $7: 3$ & $8: 2$ & $9: 1$ & $\begin{array}{l}\text { Mixing } \\
\text { ratio (MR) }\end{array}$ & $\begin{array}{l}\text { Tailing } \\
\text { species (TS) }\end{array}$ & $\begin{array}{l}\text { MR } \times \\
\text { TS }\end{array}$ \\
\hline Root & 0.11 & 0.14 & 0.16 & 0.14 & 0.25 & 0.18 & 0.17 & 0.09 & 0.16 & 0.12 & $* *$ & $* * *$ & $* *$ \\
\hline Leaf & 1.22 & 1.16 & 0.94 & 0.85 & 1.24 & 1.27 & 1.02 & 1.16 & 1.04 & 1.17 & NS & NS & NS \\
\hline Stem & 2.62 & 3.31 & 2.50 & 1.90 & 2.51 & 3.49 & 2.04 & 2.60 & 2.34 & 2.38 & $*$ & NS & $*$ \\
\hline Total biomass & 3.94 & 4.61 & 3.60 & 2.88 & 4.00 & 4.94 & 3.23 & 3.84 & 3.53 & 3.66 & NS & NS & NS \\
\hline
\end{tabular}

Date are means $(n=4) ;{ }^{* * *} p<0.001,{ }^{* *} p<0.01,{ }^{*} p<0.05$, NS: not significant by the analysis of variance.

tailings produced higher root biomass than that in other tailings $(p<0.01)$. With increasing amounts of metal tailings in the growth medium, the stem biomass of sugarcane growing in the $\mathrm{Pb} / \mathrm{Zn}$ tailings decreased $(p<0.05)$. In contrast, the stem biomass increased with $80 \%$ Sn tailings and $70 \% \mathrm{Cu}$ tailings in the growth medium compared to the control $(p<0.05)$. However, the mixing ratio of soil to the metal tailings and different mine tailings treatments had no significant effect on the leaf dry weight and the total biomass.

\subsection{Heavy metal concentration in sugarcane juice}

Compared to the control (soil only), $\mathrm{Cu}$ concentration in sugarcane juice of different stem parts increased dramatically with increasing amount of $\mathrm{Cu}$ tailings in the growth medium ( $p<0.001$, Fig. 1). $\mathrm{Zn}$ and $\mathrm{Pb}$ concentrations in the bottom, middle and top parts of sugarcane stem also increased with increasing amount of tailings $(p<$ 0.001). However, the tailings and soil mixing ratio did not influence the $\mathrm{Sn}$ concentration in sugarcane juice. As for the different sugarcane parts, the four detected heavy metal concentrations varied significantly among the bottom, middle and top parts of sugarcane stem $(p<$ $0.001) . \mathrm{Cu}, \mathrm{Pb}$ and $\mathrm{Sn}$ concentrations in sugarcane juice of the bottom part were the highest, while $\mathrm{Zn}$ concentration in the top part was the highest $(p<0.001)$.

\subsection{Heavy metal concentration in sugarcane bagasse}

Mixing ratios of soil to the tailings showed no effects on the $\mathrm{Cu}$ and $\mathrm{Sn}$ concentrations in sugarcane bagasse, however, compared with the control treatment, $\mathrm{Pb}$ and $\mathrm{Zn}$ concentration in the bagasse increased significantly $(p<$ 0.001, Fig. 2). Among different sugarcane parts, the heavy metal concentration in bagasse varied significantly. Similar results were found for the sugarcane juice, such that $\mathrm{Zn}$ concentration in the top part was the highest $(p<0.05)$ and $\mathrm{Cu}, \mathrm{Pb}$ and $\mathrm{Sn}$ concentration in the bottom part were the highest among the three stem parts $(p<0.05)$.

\subsection{Heavy metal concentration in sugarcane leaves}

The tailings: soil mixing ratio led to an increase in $\mathrm{Zn}$ concentration in sugarcane leaves $(p<0.05$, Table S1), but had no effect on the other three detected heavy metal concentrations. A significant interaction between mixing ratio and mine tailing types on $\mathrm{Pb}(p<0.05)$ and $\mathrm{Zn}(p<$ 0.01 ) concentrations of sugarcane leaf were observed. $\mathrm{Pb}$ and $\mathrm{Zn}$ concentrations in sugarcane leaf were the highest, with $90 \% \mathrm{~Pb} / \mathrm{Zn}$ tailings in the growth medium, and were almost three fold higher than those in the control treatment.

\subsection{Heavy metal concentration in sugarcane root}

With increasing amounts of tailings in the growth medium, $\mathrm{Cu}$ concentrations in sugarcane root increased $(p<0.01$, Fig. 3). The interaction between tailings types and mixing ratios was only significant for root $\mathrm{Cu}$ concentrations. In the presence of $90 \% \mathrm{Cu}$ tailings, $\mathrm{Cu}$ concentration in the sugarcane root reached $1174 \mathrm{mg} / \mathrm{kg}$ as the maximum $(p<$ $0.01)$. The tailings: soil mixing ratio also led to an increase in $\mathrm{Pb}(p<0.01), \mathrm{Zn}$ and $\mathrm{Sn}$ concentration $(p<0.001)$ in sugarcane root, reaching $726 \mathrm{mg} / \mathrm{kg}, 3742 \mathrm{mg} / \mathrm{kg}$ and 14 $\mathrm{mg} / \mathrm{kg}$, respectively.

\subsection{Heavy metal content partitioning}

Heavy metal content differed in the different parts of sugarcane. As for the sugarcane growing in the soil mixed with $\mathrm{Cu}$ mine tailings, $\mathrm{Cu}$ content in the different parts decreased in the order: root $>$ leaf $>$ juice $>$ bagasse, and $\mathrm{Cu}$ content in the root accounted for $78 \%-93 \%$ of the total $\mathrm{Cu}$ content. The transfer factor (TF, the ratio of shoot $\mathrm{Cu}$ concentration to root $\mathrm{Cu}$ concentration) and the bioconcentration factors $(\mathrm{BCF}$, the ratio of tissue $\mathrm{Cu}$ concentration to soil $\mathrm{Cu}$ concentration) were the lowest among the four detected heavy metals. The partitioning of the other three metals ( $\mathrm{Sn}, \mathrm{Pb}$ and $\mathrm{Zn}$ ) in sugarcane had similar trends, with higher metal accumulation in the root and leaf parts and lower in the bagasse and juice. The metal contents in bagasse and juice only accounted for $0.6 \%$ $3 \%$ and $0.6 \%-7 \%$ of the total metal content, respectively. The TF and BCF for different metals were all lower than 1 except for the control treatment (Table 5).

\subsection{Juice quality indexes of sugarcane}

The juice quality indexes including sucrose content, reducing sugar, fiber fraction and juice yield are related to bioethanol production. The tailings: soil mixing ratio showed no effect on the fiber fraction, juice yield and 

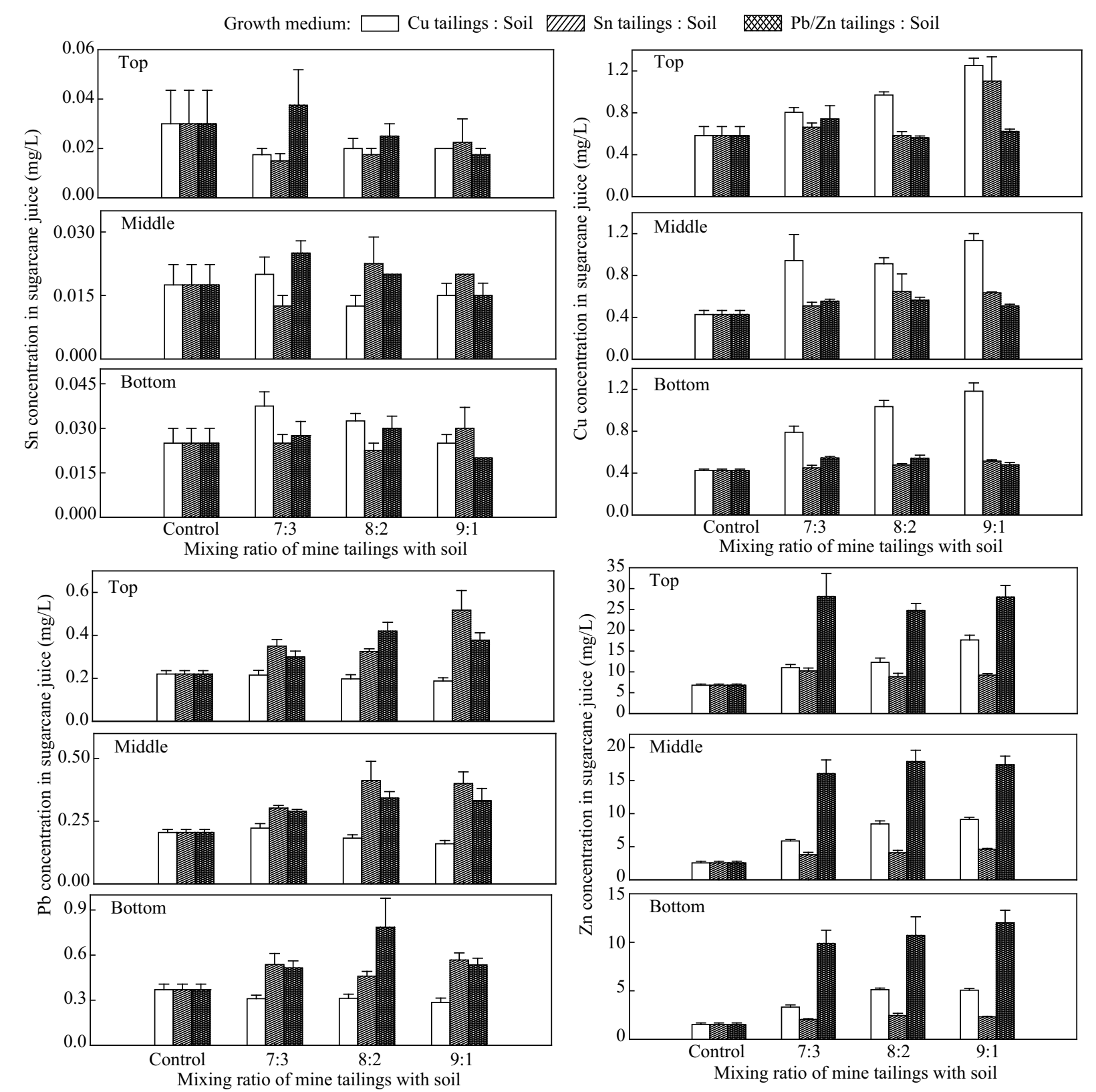

Fig. 1 Heavy metal concentrations in juice of sugarcane grown in mine tailings mixed with soil at different mixing ratios. Data are means \pm SE ( $n=4$ ). Each sugarcane stem was cut into three parts averagely from top to bottom, so the top, middle and bottom parts of each figure represent the top, middle and bottom part of sugarcane juice. By analysis of variance, mixing ratio was highly significant for $\mathrm{Cu}, \mathrm{Zn}$ and $\mathrm{Pb}$ concentration $(p<0.001)$. Sugarcane part was highly significant $(p<0.001)$ for all these four detected metals.

sucrose content in sugarcane. The interaction between tailing types and mixing ratios also showed no influence on these indexes. Furthermore, compared to the control, reducing sugar increased with increasing amount of mine tailings in the growth medium ( $p<0.01$, Table S2).

\section{Discussion}

In the present study, sugarcane showed a favorable tolerance to the mine tailings. In general, phytotoxicities would be induced with 60-125 mg/kg total Cu (Ross, 1994), 500$1000 \mathrm{mg} / \mathrm{kg} \mathrm{Pb}$ (Foy et al., 1978) and 150-300 mg/kg Zn (Macnicol and Beckett, 1985; Warne et al., 2008) in the soil. In our investigation, sugarcanes grew well in the mine tailings in which the heavy metal contents were much higher than the concentration threshold and the extractable metal concentrations were also very high. Furthermore, the mixing ratio of tailings: soil showed no significant influence on the leaf and total biomass of sugarcane (Table 4). The root biomass even increased with the proportion of tailings in the growth medium $(P<0.01$, Table 4). 
Growth medium: $\square$ Cu tailings : Soil $\mathbb{Z W}$ Sn tailings : Soil $\mathrm{Pb} / \mathrm{Zn}$ tailings : Soil
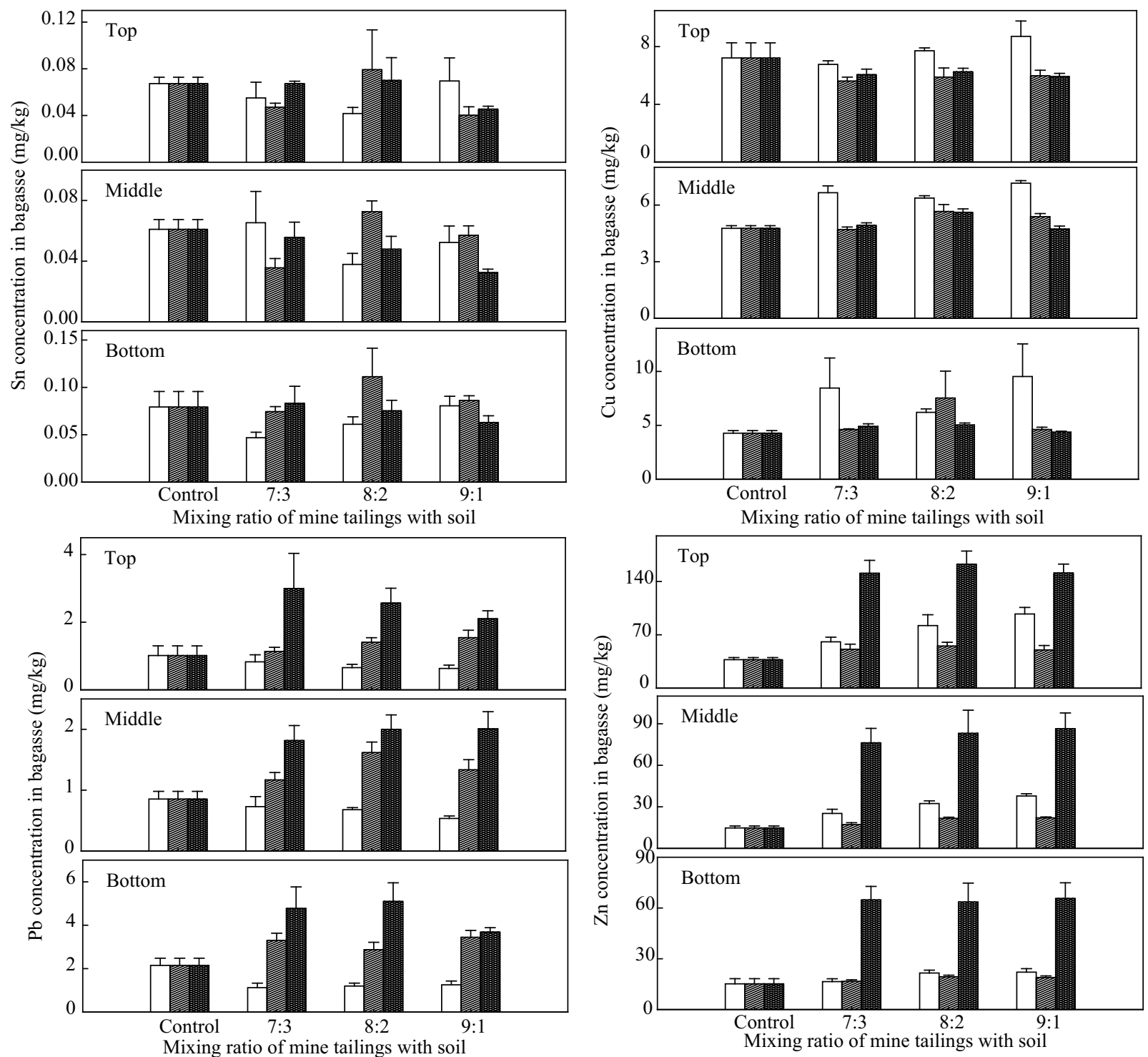

Fig. 2 Heavy metal concentrations in bagasse of sugarcane grown in mine tailings mixed with soil at different mixing ratios. Data are means \pm SE $(n=4)$. Every sugarcane stem was cut into three parts averagely from top to bottom, so the top, middle and bottom part of each figure represent the top, middle and bottom part of sugarcane bagasse. By analysis of variance, mixing ratio showed significant influence on $\mathrm{Pb}$ and $\mathrm{Zn}$ concentrations $(p<$ $0.001)$ compared with the control, but no influence on $\mathrm{Cu}$ and $\mathrm{Sn}$ concentrations. $\mathrm{Pb}$ concentration varied highly significant $(p<0.001)$ and $\mathrm{Cu}, \mathrm{Zn}$ and Sn concentration varied significantly $(p<0.05)$ among different parts of sugarcane.

These indicated that sugarcane had a very strong tolerance to heavy metal contamination. Guo et al. (2010) also found that the addition of $500 \mathrm{mg} / \mathrm{kg} \mathrm{Cu}$ in the growth medium showed no effect on the sugarcane biomass. The heavy metal tolerance of sugarcane could be due to the vigorous perennial root and huge biomass. It has a fibrous root system, with strong vitality (Blackburn, 1984). When the old roots die after harvest or in adverse conditions, new roots quickly emerge. Some old roots can retain functionality even though they appear to die (Ballcoelho et al., 1992). On the other hand, sugarcane is a C4 plant with high photosynthetic efficiency. It can sustain superior growth over most other crop species (Alexander, 1973).
The higher biomass of sugarcane could lead to a "growth dilution effect" on metals and subsequently alleviate metal phytotoxicity.

In our investigation we also observed that amendment of $20 \%$ soil to $\mathrm{Sn}$ tailings and $30 \%$ soil to $\mathrm{Cu}$ tailings could facilitate the biomass of cane-stem, which is directly related to the bioethanol production (Table 4). Amendment with higher amounts of clean soil stimulated plant growth, possibly by improving plant mineral nutrition and dilution effects on potentially toxic heavy metals. As shown in Table 3, neutralization of the high alkalinity of tailings by amended soil could make the growth medium more favorable for plant growth (Chen et al., 2008). However, 

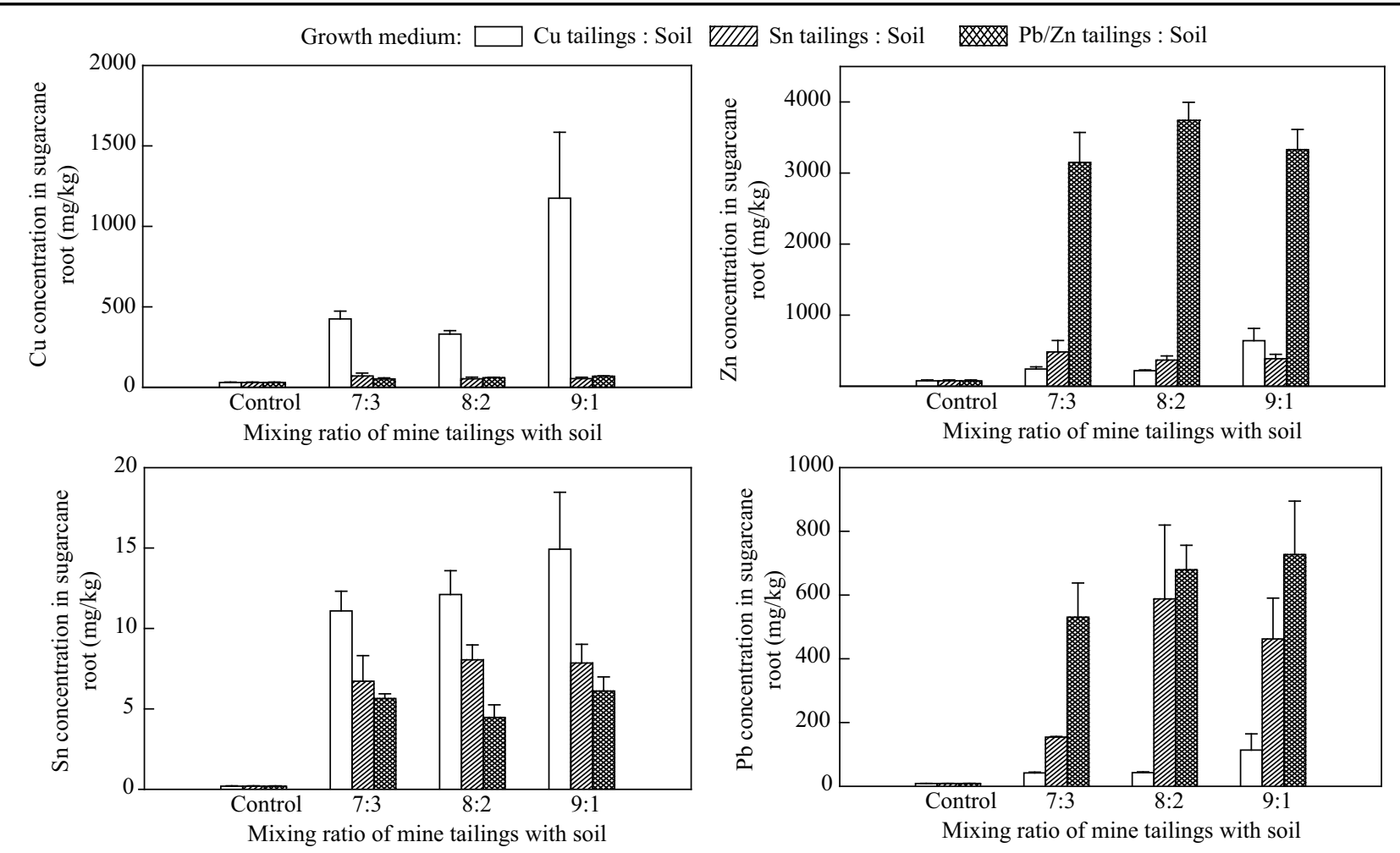

Fig. 3 Heavy metal concentrations in root of sugarcane grown in mine tailings mixed with soil at different mixing ratios. Data are means \pm SE ( $n=4$ ). By analysis of variance, mixing ratio showed significant influence on $\mathrm{Cu}$ and $\mathrm{Pb}$ concentration $(p<0.01)$ and dramatically significant influence on $\mathrm{Sn}$ and $\mathrm{Zn}$ concentration $(p<0.001)$. Tailings treatments were highly significant for all the detected metals $(p<0.001)$. The interaction between tailings treatments and mixing ratio was significant for $\mathrm{Cu}$ concentrations $(p<0.01)$.

the different bioavailability of heavy metals in the tailings: soil mixtures and their different physiological functions might explain different plant growth responses. In practice, to obtain more production of sugarcane stem, mixing a certain amount of soil into tailings is sometimes required. The experimental results from the present study postulated an alternative solution for tailings reclamation, which might not only reduce quantities of soils needed for reclamation but also bring financial benefits from increasing raw material for bioethanol production.

Sugarcane is considered to be a metal tolerant plant that can also serve as an energy crop. Its metal partition and accumulation are key characteristics for bioethanol production and other usage. In the present study, metal concentrations in roots were significantly higher than in any other parts of sugarcane (Fig. 3) and the TF and $\mathrm{BCF}$ indexes of sugarcane growing in different tailings were all lower than 1 (Table 5). This suggested that sugarcane could not serve as a metal hyperaccumulator but as a good candidate for stabilization of $\mathrm{Cu}, \mathrm{Sn}, \mathrm{Pb}$ and $\mathrm{Zn}$ tailings, which may reduce metal mobilization and environmental risks in the plant-soil continuum and ecosystem. According to the principle that the lower the $\mathrm{TF}$ in different tailings, the more restriction of metal translocation to shoot, the translocation potential of $\mathrm{Cu}$ was the lowest among these four detected metals. As for the metal partitioning, the majority of $\mathrm{Cu}$ accumulated in the root of sugarcane, accounting for $78 \%-93 \%$ of the total $\mathrm{Cu}$ content (Table 5). The possible reason for this might be the binding of $\mathrm{Cu}$ to roots, poor $\mathrm{Cu}$ transport in xylem or counter flow of $\mathrm{Cu}$ in the phloem back to roots (Liao et al., 2000). Different from Cu contents, most Sn, $\mathrm{Pb}$ and $\mathrm{Zn}$ was accumulated in the roots and leaves of sugarcane (Table 5). The heavy metal retention in roots is based on binding of heavy metals to negatively charged cell walls and also extracellular precipitation, which restricts its transport via apoplast (Sharma and Dubey, 2005). This is a common strategy for most plant species (except for hyperaccumulators) to resist heavy metal toxicity. Though the concentrations of $\mathrm{Sn}, \mathrm{Pb}$ and $\mathrm{Zn}$ in the root were the highest, the biomass of leaf is about 7 fold higher than that of root, resulting in higher metal contents in the leaf part. However, after sugarcane is harvested, cane-leaf would be returned to the tailings. Leaf-returning, on one hand, can fertilize soil and promote sugarcane growth and yield; on the other hand, for phytostabilization purposes, such a practice would also inhibit the metal transfer via the food chain and subsequently reduce environmental risks.

Besides metal accumulation by root and leaf, the most attractive characteristic of sugarcane is the potential to produce green biofuels. As an energy crop, the juice and bagasse of sugarcane are the most valuable parts 
Table 5 Heavy metal contents of different parts of sugarcane, transfer factor and bioconcentration factor

\begin{tabular}{|c|c|c|c|c|c|c|c|}
\hline \multirow{2}{*}{$\begin{array}{l}\text { Mixing ratio } \\
\text { Tailings:Soil }\end{array}$} & \multicolumn{7}{|c|}{ Parts of sugarcane } \\
\hline & Root & Leaf & Bagasse & Juice & Whole plant & $\mathrm{TF}$ & $\mathrm{BCF}$ \\
\hline Cu tailings:Soil & \multicolumn{7}{|c|}{$\mathrm{Cu}$ content $(\mathrm{mg})$} \\
\hline Control & 1.05 & 2.17 & 0.73 & 0.76 & 4.71 & 0.13 & 0.018 \\
\hline $7: 3$ & 23.27 & 2.87 & 1.04 & 1.61 & 28.79 & 0.01 & 0.001 \\
\hline $8: 2$ & 19.83 & 1.74 & 0.97 & 1.61 & 24.15 & 0.01 & 0.001 \\
\hline $9: 1$ & 68.92 & 1.71 & 1.05 & 1.40 & 73.08 & 0.01 & 0.007 \\
\hline Sn tailings:Soil & \multicolumn{7}{|c|}{ Sn content (mg) } \\
\hline Control & 0.01 & 0.64 & 0.01 & 0.02 & 0.68 & 3.9 & 0.03 \\
\hline $7: 3$ & 0.45 & 0.78 & 0.01 & 0.03 & 1.27 & 0.20 & 0.007 \\
\hline $8: 2$ & 0.45 & 0.68 & 0.02 & 0.04 & 1.19 & 0.09 & 0.006 \\
\hline $9: 1$ & 0.51 & 0.65 & 0.01 & 0.03 & 1.20 & 0.10 & 0.008 \\
\hline $\mathrm{Pb} / \mathrm{Zn}$ tailings:Soil & \multicolumn{7}{|c|}{$\mathrm{Pb}$ content $(\mathrm{mg})$} \\
\hline Control & 0.3 & 33.7 & 0.18 & 0.47 & 34.65 & 4.32 & 0.02 \\
\hline $7: 3$ & 23.84 & 32.64 & 0.35 & 0.64 & 57.47 & 0.05 & 0.008 \\
\hline $8: 2$ & 26.62 & 32.43 & 0.41 & 0.83 & 60.29 & 0.06 & 0.008 \\
\hline $9: 1$ & 30.89 & 58.67 & 0.35 & 0.65 & 90.56 & 0.08 & 0.012 \\
\hline $\mathrm{Pb} / \mathrm{Zn}$ tailings:Soil & \multicolumn{7}{|c|}{$\mathrm{Zn}$ content $(\mathrm{mg})$} \\
\hline Control & 2.74 & 86.13 & 3.00 & 5.05 & 96.92 & 1.44 & 0.19 \\
\hline $7: 3$ & 135.80 & 126.13 & 9.97 & 23.85 & 295.75 & 0.04 & 0.008 \\
\hline $8: 2$ & 148.57 & 138.81 & 12.83 & 25.67 & 325.88 & 0.05 & 0.008 \\
\hline $9: 1$ & 135.28 & 236.54 & 13.22 & 25.66 & 410.7 & 0.08 & 0.012 \\
\hline
\end{tabular}

TF: transfer factor; BCF: bioconcentration factor.

(Nguyen et al., 2009), so metal contents in these two parts are the most basic concerns for sugarcane growing in mine tailings. Overly high levels of metal contents in the juice or bagasse would finally lead to metal-rich biofuels and cause secondary environmental contamination. In the present study, the metal contents in bagasse and juice were very low, accounting for $0.6 \%-3 \%$ and $0.6 \%-7 \%$ of the total metal content, respectively (Table 5). The low metal contents in bagasse and juice could be ascribed to the limited transport of heavy metals from roots to shoots. It appears that heavy metals move predominately into the root apoplast and thereby in a radical manner across the cortex, and accumulate near the endodermis. The endodermis acts as a partial barrier to the movement of heavy metals between roots and shoots (Sharma and Dubey, 2005). Despite everything, such low metal content in the raw material for biofuels is certainly an advantage to produce environmentally safe ethanol.

Even though metal contents in the stem were low, metals in sugarcane may not necessarily evenly distribute in the stem. In order to obtain safer raw material for production of biofuels or other byproducts, sugarcane stem was separated roughly into bottom, middle and top parts and metal concentrations of each part were determined. Similar tendencies, such that the highest $\mathrm{Cu}, \mathrm{Pb}$ and $\mathrm{Sn}$ concentrations occurred in the bottom part in contrast to the highest $\mathrm{Zn}$ concentration being found in the top part, were found both in the juice $(p<0.001$, Fig. 1) and bagasse $(p<0.05$, Fig. 2). The results gave guidance that based on different cane-stem usages, choosing different parts of the stem for processing would be a wise move.

It is a sustainable reclamation practice to use energy crops for stabilization of solid wastes (tailings), which can meanwhile bring economic benefits. On average, bioethanol production per hectare sugarcane cropland is $5160 \mathrm{~L}$ (Su and Lee, 2009), equivalent to 22,500-32,400 CNY (Tang, 2004). In Brazil, half of the cane produced is destined for bioethanol to feed an increasing number of flex-fuel cars. In 2008, 2,254,553 flex-fuel cars using bioethanol were sold, which was 3.5 times the number of gasoline powered cars (Waclawovsky et al., 2010). Bioethanol fromsugarcaneis an alternative energy source to reduce the dependency of regional economies on fossil fuels, which is considered to be a beneficial and cost-effective greenhouse gas mitigation strategy. In our investigation, we found that compared to the control treatment, the soil: tailings mixing ratio showed no effect on the indexes related to bioethanol production, including fiber fraction, juice yield and sucrose content (Table S2). This suggested that the production of bioethanol would 
not be negatively influenced for the sugarcane growing on the mine tailings. Furthermore, we found that reducing sugar increased with increasing amount of mine tailings in the growth medium ( $p<0.01$, Table S2). Increased amount of reducing sugar is beneficial for the production of bioethanol, which would bring more economic benefit. In addition to ethanol production, about 37 byproducts of commercial importance are produced, with a value of approximately US $\$ 8000$ per ton of raw material. Highvalue byproducts of the cane industry include monosodium glutamate from molasses, furfural and cellulose from bagasse, and lysine, industrial alcohol and yeast (Hunsigi, 1993). Clearly, sugarcane has a wide array of applications associated with high economic value and could bring more benefit to the local communities.

As fossil fuel prices continue to escalate and greenhouse effects become increasingly serious, more and more opportunities open up for plant-based fuel production. To cultivate sugarcane in tailings would not compete for land required for food production, and therefore could have a bright future. Our pot experiment, although still a preliminary phase for a novel reclamation practice, at least demonstrated the possibility of combining environmental pollution control and bioenergy production. Before large scale practice, small-scale field experiment and pilot demonstration is certainly very necessary. The cost benefit analyses for the combined use of sugarcane in the biofuel industry and for phytoremediation of tailings should also be addressed in future research.

\section{Conclusions}

The present study has demonstrated the potential use of sugarcane for phytostabilization of metal mine tailings and bioenergy production. The experimental data supported the strong tolerance of sugarcane to metal-contaminated environments. More importantly, the high metal concentrations in the root provided advantages for phytostabiliztion, while the lower metal contents in the cane-stem guaranteed a safe energy raw material. Furthermore, the juice qualities related to the bioethanol production were not influenced by the tailings in the growth medium. Our results also suggested that mixing a certain amount of soil into tailings could serve as an alternative practice for assisting tailing reclamation.

\section{Acknowledgments}

This work was supported by the National Key Technology Research and Development Program of China during the "12th Five-Year Plan" (No. 2012BAC25B03), the Natural Science Foundation of China (No. 41101246), the National Sugarcane Industry Technical System (No. CARS-20-34) and Modern Agriculture Sugarcane Industry Technical System of Yunnan Province.

\section{Supporting materials}

Supplementary data associated with this article can be found in the online version.

R E F E R E N C E S

Alexander, A.G., 1973. Sugarcane Physiology, A Comprehensive Study of the Saccharum Source-to-Sink System. Elsevier Scientific Publishing Co., Amsterdam.

Amorim, H.V., Lopes, M.L., Oliveira, J.V.D., Buckeridge, M.S., Goldman, G.H., 2011. Scientific challenges of bioethanol production in Brazil. Appl. Microbiol. Biot. 91(5), 1267-1275.

Ballcoelho, B., Sampaio, E., Tiessen, H., Stewart, J.W.B., 1992. Root dynamics in plant and ratoon crops of sugar cane. Plant Soil 142(2), 297-305.

Blackburn, F., 1984. Sugar-cane. Longman Group Ltd., Singapore.

Chen, B., Roos, P., Zhu, Y.G., Jakobsen, I., 2008. Arbuscular mycorrhizas contribute to phyto stabilization of uranium in uranium mining tailings. J. Environ. Radioactiv. 99(5), 801-810.

Danh, L.T., Truong, P., Mammucari, R., Foster, N., 2011. Economic incentive for applying vetiver grass to remediate lead, copper and zinc contaminated soils. Int. J. Phytoremediat. 13(1), 47-60.

Foy, C., Chaney, R., White, M., 1978. The physiology of metal toxicity in plants. Annu. Rev. Plant Physiol. 29(1), 511-566.

Guo, J.W., Cui, X.X., Zhang, Y.B., Liu, S.C., 2010. Cu uptake by sugarcane and its effects on sugarcane yield and quality. Soils 42(4), 606-610.

Guo, J.W., Zhang, Y.B., Cui, X.W., Liu, S.C., Dao, J.M., Fan, X., 2012. Accumulation of N, P, K and their effects on sugarcane yield and quality. Soils 44(6), 977-981.

Hargreaves, J., Lock, A., Beckett, P., Spiers, G., Tisch, B., Lanteigne, L. et al., 2012. Suitability of an organic residual cover on tailings for bioenergy crop production: A preliminary assessment. Can. J. Soil Sci. 92(1), 203-211.

Hunsigi, G., 1993. Production of Sugarcane: Theory and Practice. Springer Verlag, Berlin, Germany.

Kien, C.N., Noi, N.V., Son, L.T., Ngoc, H.M., Tanaka, S., Nishina, T. et al., 2010. Heavy metal contamination of agricultural soils around a chromite mine in Vietnam. Soil Sci. Plant Nutr. 56(2), 344-356.

Li, M.S., 2006. Ecological restoration of mineland with particular reference to the metalliferous mine wasteland in China: A review of research and practice. Sci. Total. Environ. 357(1-3), 38-53.

Li, M.S., Luo, Y.P., Su, Z.Y., 2007. Heavy metal concentrations in soils and plant accumulation in a restored manganese mineland in Guangxi, South China. Environ. Pollut. 147(1), 168-175.

Liao, M.T., Hedley, M.J., Woolley, D.J., Brooks, R.R., Nichols, M.A., 2000. Copper uptake and translocation in chicory (Cichorium intybus L. cv Grasslands puna) and tomato (Lycopersicon esculentum Mill. cv Rondy) plants grown in NFT system. II. The role of nicotianamine and histidine in xylem sap copper transport. Plant Soil 223(1), 245-254.

Lindsay, W.L., Norvell, W.A., 1978. Deveopment of a DTPA soil test for zinc, iron, manganese and copper. Soil Sci. Soc. Am. J. 42(3), 421428.

Liu, C.F., Li, Y.H., Shi, G.R., 2012. Utilize heavy metal-contaminated farmland to develop bioenergy. In: Li, D.W. (Eds.), Contaminated Sites Remediation. Trans Tech Publications Ltd, Stafa-Zurich, pp. 
254-261.

Macnicol, R.D., Beckett, P.H.T., 1985. Critical tissue concentrations of potentially toxic elements. Plant Soil 85(1), 107-129.

Mendez, M.O., Glenn, E.R., Maier, R.M., 2007. Phytostabilization potential of quailbush for mine tailings: Growth, metal accumulation, and microbial community changes. J. Environ. Qual. 36(1), 245253.

Nguyen, T.L.T., Hermansen, J.E., Sagisaka, M., 2009. Fossil energy savings potential of sugar cane bio-energy systems. Appl. Energ. 86(S1), S132-S139.

Olivares, A.R., Carrillo-González, R., González-Chávez, M.D.A., SotoHernández, R.M., 2013. Potential of castor bean (Ricinus communis L.) for phytoremediation of mine tailings and oil production. $\mathrm{J}$. Environ. Manage. 114, 316-323.

Richards, L.A., 1954. Diagnosis and improvement of saline and alkali soils. Soil Science 78(2), 154.

Rosario, K., Iverson, S.L., Henderson, D.A., Chartrand, S., McKeon, C., Glenn, E.P. et al., 2007. Bacterial community changes during plant establishment at the San Pedro River mine tailings site. J. Environ. Qual. 36(5), 1249-1259.

Ross, S., 1994. Sources and forms of potentially toxic metals in soil-plant systems. In: Ross, S.M. (Eds.), Toxic Metals in Soil-Plant Systems. John Wiley \& Sons, Chichester, UK, pp. 3-26.

Sereno, M.L., Almeida, R.S., Nishimura, D.S., Figueira, A., 2007. Response of sugarcane to increasing concentrations of copper and cadmium and expression of metallothionein genes. J. Plant Physiol. 164(11), 1499-1515.

Sharma, P., Dubey, R.S., 2005. Lead toxicity in plants. Brazilian Journal of Plant Physiology 17(1), 35-52.

Smith, D.M., Inman-Bamber, N.G., Thorburn, P.J., 2005. Growth and function of the sugarcane root system. Field. Crop. Res. 92(2-3), 169-183.

Souza, S.P., de Avila, M.T., Pacca, S., 2012. Life cycle assessment of sugarcane ethanol and palm oil biodiesel joint production. Biomass. Bioenerg. 44, 70-79.

Su, C.L., Lee, Y.M., 2009. Development status and life cycle inventory analysis of biofuels in Taiwan. Energ. Policy 37(2), 754-758.
Tang, X.P., 2004. Energy sugarcane, the best material for fuel alcohol production. Sugarcane 11(2), 30-32.

Van Ginneken, L., Meers, E., Guisson, R., Ruttens, A., Elst, K., Tack, F.M.G. et al., 2007. Phytoremediation for heavy metalcontaminated soils combined with bioenergy production. J. Environ. Eng. Landsc. 15(4), 227-236.

Waclawovsky, A.J., Sato, P.M., Lembke, C.G., Moore, P.H., Souza, G.M., 2010. Sugarcane for bioenergy production: an assessment of yield and regulation of sucrose content. Plant Biotechnol. J. 8(3), 263276.

Wahid, A., 2004. Analysis of toxic and osmotic effects of sodium chloride on leaf growth and economic yield of sugarcane. Bot. Bull. Acad. Sinica 45(2), 133-141.

Wahid, A., Rao, A.U.R., Rasul, E., 1997. Identification of salt tolerance traits in sugarcane lines. Field. Crop. Res. 54(1), 9-17.

Warne, M.S.J., Heemsbergen, D., McLaughlin, M., Bell, M., Broos, K., Whatmuff, M. et al., 2008. Models for the field-based toxicity of copper and zinc salts to wheat in 11 Australian soils and comparison to laboratory-based models. Environ. Pollut. 156(3), 707-714.

Witters, N., Mendelsohn, R.O., Van Slycken, S., Weyens, N., Schreurs, E., Meers, E., et al., 2012. Phytoremediation, a sustainable remediation technology? Conclusions from a case study. I: Energy production and carbon dioxide abatement. Biomass. Bioenerg. 39, 454-469.

Wong, M.H., 2003. Ecological restoration of mine degraded soils, with emphasis on metal contaminated soils. Chemosphere 50(6), 775780 .

Xia, H.L., Yan, Z.J., Chi, X.Y., Cheng, W.W., 2009. Evaluation of the phytoremediation potential of Saccharum officinarum for Cdcontaminated soil. In: Proceedings of the International Conference on Energy and Environment Technology. IEEE, Guiling, China, pp. 314-318.

Ye, Z.H., Shu, W.S., Zhang, Z.Q., Lan, C.Y., Wong, M.H., 2002. Evaluation of major constraints to revegetation of lead/zinc mine tailings using bioassay techniques. Chemosphere 47(10), 11031111 . 